\title{
Эпигенетические механизмы кариогеномной системы зрелых зародышей пшеницы, выведенной в условиях холодового стресса
}

\author{
Иванова Э.А.*, Вафина Г.Х. \\ Уфимский институт биологии УФИЦ РАН, Уфа, Россия \\ *e-mail: fiona_belobor@mail.ru
}

Пониманием базовой основы закономерностей морфогенетического развития, особенно в условиях гибридизации растений, занимается биоинформационная наука, которая с этой целью разрабатывает эффективные информационнокомпьютерные технологии, исходя из того, что в основе любого признака лежит генная сеть - функциональная группа координированно экспрессирующихся генов. В ряде таких работ виртуально выделен их блочно-модульный характер, где блоки генных сетей образуют иерархическую структуру, в которой включение порядка и времени соответствуют формированию морфофизиологических компартментов. Связь между блоками генных сетей осуществляют сигнальные молекулы. По сравнению с биохимическими признаками молекулярные механизмы адаптивной эволюции морфогенетических признаков изучены слабо. В настоящее время методический прогресс сильно продвинул понимание молекулярно-генетической организации интерфазного ядра. Становится очевидным, что функциональная динамика доменной топологии интерфазного хроматина вовлечена в контроль регуляции различных взаимосвязанных базовых процессов в определенных областях ядра. Мы предположили, что один из механизмов в супрадоменной реорганизации хроматиновой матрицы может выполнять $\operatorname{Arg}-X$ протеазо-процессинг. Это предположение основывается на том, что хроматин ядра богат аргинином, и из всех аминокислот только он способен связываться с определенными пуриновыми и пиримидиновыми основаниями ДНК. Целью данной работы было рассмотрение кариогеномного анализа локализации $A r g-X$ процессинга в топологически ассоциированных супраблоках гексаплоидной системы интерфазного хроматина в зрелых зародышах пшениц, адаптированных к холодовому стрессу. Объектом исследования служили семена суперэлиты пшениц (Triticum aestivum L.) сорта Артемовка (яровая) и выведенного из нее сорта Мироновская 808 (озимая), полученных из коллекции Всероссийского института растениеводства им. Н.И. Вавилова. Экспериментальная работа была проведена на основе собственных патентов: (1) по оценке морфофизиологического состояния проклюнувшихся зародышей; (2) выделенных из них клеточных ядер и (3) их супраструктурных ансамблей, а также (4) негистоновых и гистоновых белков, в которых (5) выявлена локализация $\mathrm{Arg}-X$ протеазо-процессинга. Впервые экспериментальные данные по эпигенетическим механизмам кариогеномного интерфазного хроматина гексаплоидной пшеницы представлены методами эпибиохимии с применением терминологии кариогеномики. Выявлены зоны локализации $A r g-X$ протеазо-процессинга в негистоновых и коровых гистонах, топологически ассоциированных кариогеномных доменах, в клеточных ядрах мезокотилей вегетативного периода ростового морфогенеза зрелых зародышей пшеницы, адаптированной к холодовому стрессу. Приведенные данные необходимы для разработки логико-математических схем теории и практики биологической специфичности и могут войти в базу данных онтологии стадий роста и развития кариогеномных растений. 